\title{
EFFECT OF BED MATERIAL TYPE ON COMBUSTION EFFICIENCY OF FLUIDIZED BED COMBUSTOR
}

\author{
Shabaan, M. M \\ Department of Mechanical Power Engineering, \\ Faculty of Engineering, Suez Canal University, Egypt
}

\begin{abstract}
Liquefied petroleum gas LPG as well as solid fuels like coal and wood ships are used in fluidized bed technology for a wide range of applications. The characteristics of fluidized bed combustion using limestone and sand as bed materials with particles diameter of $0.7-1 \mathrm{~mm}$ were studied experimentally. An experimental test rig has been designed and manufactured to produce a good fluidization in a wide range of operating conditions. Cold experiments were carried before hot experiments to predict the suitable initial bed height, which has been seen to be $3-\mathrm{cm}$. LPG fuel, has been used as a gaseous fuel and A/F ratio considered constant during all experiments. The effects of bed material on gas temperature distribution along the combustor height are investigated and presented in the present work. The combustion of coal and wood ships in fluidized bed combustor was verified by adding a continuous flow rates with lesser quantities of LPG. The photos of the bed in cold and hot states are presented. The heat transfer to the combustor wall was measured from the increase of the cooling water enthalpy and then the combustion efficiency was calculated. The results show the great dependent of the parameters under study on the bed characteristics.

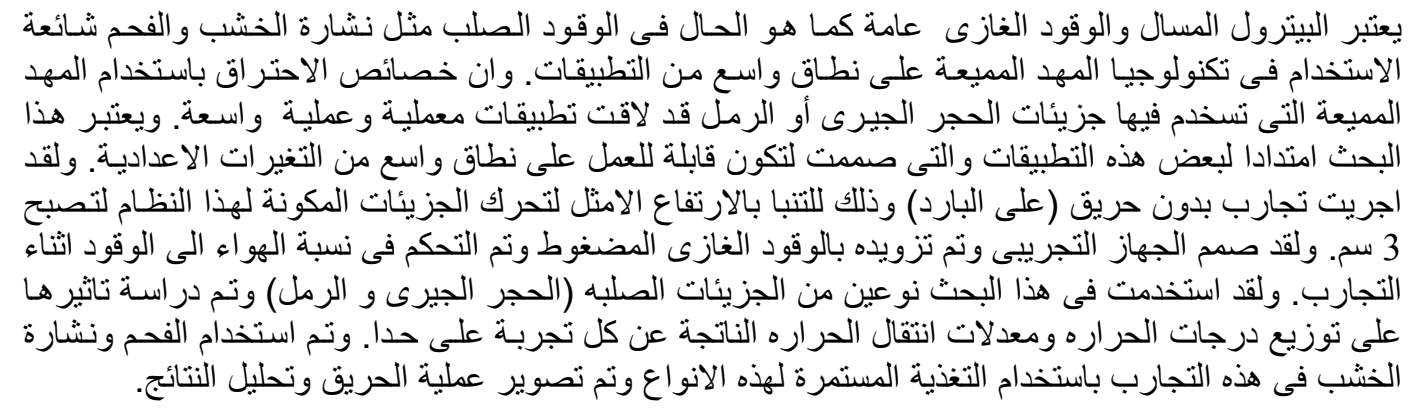

Keywords: Fluidized Bed, Limestone, Sand, Gaseous fuels, Coal, Wood ships

\section{INTRODUCTION}

Fluidized bed combustion: The basic aim of FBC technology was to enable utilization of coals with high sulphur content, while simultaneously fulfilling its strict environmental protection regulations. From the very beginning, work focused on the development of large boilers, mainly for utility electric energy production. Another objective was the utilization of large amounts of waste coal, left after the separation, washing and enrichment of high-rank coals. Utilization of wood waste in the timber industry, peat and other waste fuels was favored. Utilization of industrial and city waste was very important, in addition to interest in using fuels such as biomass and waste coals. Technical, economic and ecological conditions for coal utilization, as well as reasons for $\mathrm{FBC}$ technology development, differ for small and medium power plants and large boilers. A fluidized-bed (FB) is obtained by passing a fluid at a sufficient rate up through a mass of solid particles held in a (often cylindrical) vessel. As the name indicates, the action of passing the fluid up through the mass of particles causes it to take on fluid like Properties. The size and shape of the particles varies depending on the application but in most industrial contexts particles are rounded in shape and have diameters between 30 and $1000 \mu \mathrm{m}$. In furnaces of FBC boilers with stationary, bubbling beds, specific conditions for heat transfer exist.Compared to the conventional boilers there are two major differences: combustion temperature is lower $\left(800-900{ }^{\circ} \mathrm{C}\right)$, and solid particle concentration (not only in the fluidized bed) is much higher. So, heat transfer by radiation is a less important process in FBC boilers. In conventional boilers heat energy is transferred by two mechanisms - gas convection and radiation, while in FBC boilers three mechanisms are in effect: radiation, gas convection and heat transfer by contact of solid particles [1]. 
Fluidized bed combustion technology has proven to be a suitable technology for converting a wide range of agricultural residues into energy due to its inherent advantages of fuel flexibility, low operating temperature and isothermal operating condition. Fluidized-bed conversion of solid fuels is a wellestablished and widely used technology. Yet, operational problems are encountered in industrial practice. In particular, the thermal conversion of certain biomass fuels, which is becoming increasingly popular, increases the risk of agglomeration. This paper critically reviews the current research status of this topic in terms of agglomeration mechanisms, detection and counteraction strategies. Different methods to counteract agglomeration phenomena are presented; they comprise operational measures, utilization of additives, alternative bed materials and improved reactor design [2]. For both ecological and economical reasons, fluidized-bed technologies are frequently used for the incineration of sewage and paper sludges, and pretreated wastes. This effective technology offers complete combustion, generates small amounts of flue gas with low contaminant concentration and requires no or very little auxiliary fuels. Fluidized bed technology has proved its worth in more than 60 facilities. The heat value of the particular waste stream being processed will determine whether a stationary or circulating fluidized bed is preferred. Fluidized bed conversion of carbonaceous solid material (e.g. coal, biomass, etc.) at high temperatures is industrial practice to generate steam, electricity and hydrogen. The solid fuel is added to a fluidized bed of inert solid material, which acts as a heat reservoir. Silica sand is most commonly used as bed material. The actual amount of the fuel itself in the bed as compared to the inert bed material is relatively low, in the order of a few per cent. The fluidized bed material ensures good mixing of the introduced fuel as well as the evolving heat. The homogeneous temperature distribution is one of the important advantages of fluidized beds over other reactor concepts. Depending on the process, heat can either be directly utilized or the evolving gases can be processed to produce liquid fuels.

Fluidized beds are used for a variety of applications in the process industry, such as fluidized catalytic cracking (FCC) including catalyst generation and other strongly exothermal processes, drying, solid fuel conversion and gas-phase polymer production [3].Fluidized-bed advantages: 1- Emissions lower than the most common combustion system. 2Uniform bed temperature $\left(500-950^{\circ} \mathrm{C}\right)$. 3- Safe and simple operation. 4- Up to $40 \%$ lower maintenance cost, because there is no moving parts. 5- No or very little auxiliary fuel is required, which helps to reduce operating cost. 6- Lowest air pollution even for low grade coals which high sulfur contents (reduced NOx due to lower combustion temperature). 7- Any type of fuel (liquid, gas and solid) can be used. 8- Coal can be used for open-cycle gas turbine with fluidized-bed firing system. 9- It can be more economically used for combined-cycle power plants. 10- Lower exhaust gas temperature, thus the thermal efficiency is higher. 11- Reduce $\mathrm{SO}_{\mathrm{x}}$ by $90 \%$ when limestone is bed particulates. $\mathrm{Ca} \mathrm{CO}_{3}+1 / 2 \mathrm{O}_{2}+\mathrm{SO}_{2}$ $=\mathrm{Ca} \mathrm{SO}_{4}+\mathrm{CO}_{2}$.

Fluidized-bed disadvantages: 1- Erosion all parts of fluidized-bed unit are subjected to erosion by the solid particles. 2- Loss of fine solids Loss of fine solids from the bed reduced the quality of fluidization and reduced the area of contact between solids and the gas. 3- Loss of fluidizing gas loss of fluidizing gas will lead to collapse of the fluidizedbed. In this case, the heat will not be dissipated as well from the packed-bed as it was from the fluidized-bed. The heat transfer in fluidized-bed combustors is better than any combustion system because the heat transfer by radiation from solid particles [1].Fluidized bed powder: Geldart classified powders into four groups according to their fluidization properties at ambient conditions. The Geldart Classification of Powders is now used widely in all fields of powder technology. Group A powders, when fluidized by air at ambient conditions, give a region of non-bubbling fluidization beginning at $\mathrm{U}_{\mathrm{mf}}$, followed by bubbling fluidization as fluidizing velocity increases. Group B powders give only bubbling fluidization under these conditions. Geldart identified two further groups. Group C powders - very fine, cohesive powders, which are incapable of fluidization in the strict sense. Group D powders are large particles that are distinguished by their ability to produce deep spouting beds. The fluidization properties of a powder in air may be predicted by establishing in which group it lies. It is important to note that at operating temperature and pressures above ambient a powder may appear in a different group from that which it occupies at ambient conditions. This is due to the effect of gas properties on the grouping and may have serious implications as far as the operation of the fluidized bed is concerned [4]. Gas-particle fluidization enables intimate contact between a particle and a fluid, hence making effective use of the surface area of the particle. One complexity of a fluidized bed is that its hydrodynamic behavior depends on the scale of the bed. From the point of view of plant design, it is important to be able to predict the performance of a large-scale system based on lab scale experiments. This has led to some useful contributions in studying the scaling laws of fluidized beds [5]. If we introduce into the moving gas stream a number of particles with a range of particle size some particles may fall and some may rise depending on their size and their 
radial position. Thus the entrainment of particles in an upward-flowing gas stream is a complex process. We can see that the rate of entrainment and the size distribution of entrained particles will in general depend on particle size and density, gas properties, gas velocity, gas flow regime-radial velocity profile and fluctuations and vessel diameter. In addition (i) the mechanisms by which the particles are ejected into the gas stream from the fluidized bed are dependent on the characteristics of the bed - in particular bubble size and velocity at the surface, and (ii) the gas velocity profile immediately above the bed surface is distorted by the bursting bubbles. This empirical approach defines coarse particles as particles whose terminal velocities are greater than the superficial gas velocity $\mathrm{U}_{\mathrm{T}}>\mathrm{U}$ and fine particles as those for which $\mathrm{U}_{\mathrm{T}}<\mathrm{U}$; and considers the region above the fluidized bed surface to be composed of several zones: 1- Freeboard. Region between the bed surface and the gas outlet. 2- Splash zone. Region just above the bed surface in which coarse particles fall back down. 3- Disengagement zone. Region above the splash zone in which the upward flux and suspension concentration of fine particles decreases with increasing height. 4- Dilute-phase transport zone. Region above the disengagement zone in which all particles are carried upwards; particle flux and suspension concentration are constant with height [6].Gas Distributor: The distributor is a device designed to ensure that the fluidizing gas is always evenly distributed across the cross-section of the bed. It is a critical part of the design of a fluidized bed system. Good design is based on achieving a pressure drop which is a sufficient fraction of the bed pressure drop. Readers are referred to Geldart for guidelines on distributor design. Many operating problems can be traced back to poor distributor design [7]. In a gas-solid fluidized bed, gas mixing has been regarded as an important property. For commercial applications, the high efficiency of fluid-solid contact is usually emphasized. Therefore, how to enhance the gas-solid mixing in a fluidization operation is focused [8].It was suggested that the radial gas mixing increased with the fluidizing velocity and reaches maximum value when turbulent fluidization regime is approached. Radial gas mixing has been also studied extensively in fast or circulating fluidized beds [9-10].

Combustion of gaseous fuel: Methane, LPG (liquid petroleum gas) and aromatic hydrocarbon vapors in a bubbling fluidized bed has been burned in a laboratory size quartz reactor. Gaseous fuels are used in fluidized bed technology for a wide range of applications, e.g., co-firing, gas re-burn and direct combustion for heating fluidized beds in some industrial processes. But the combustion of gaseous fuels in fluidized beds has received less attention and is still at the stage of laboratory investigations [11].
Two different ways have been used to supply gaseous fuels for burning in fluidized beds: premixing and non-premixing. The most important thing for combusting gaseous fuels efficiently is to mix gaseous fuels with air well. But this is not easy for non-premixed combustion especially for gaseous fuels possessing a high calorific value. The most effective method for improving the combustion is to premix air and gaseous fuels before they are introduced into a bed. So far, the combustion of gaseous fuels reported for bubbling regime fluidized beds is mostly for premixed combustion. Whereas, premixed combustion may cause some troubles in operation safety. When a fluidized bed operates at high temperature continuously for a long time, heat may transfer downward from the bed to the distributor because the fluidized red-hot particles contact with the distributor directly or the defluidized layer covering the distributor, so the temperature of the distributor rises. The pre-mixed gaseous fuel and air in the plenum chamber under the distributor could explode if the temperature of the distributor reaches a certain value. This makes a serious problem in the applications of gas fluidized bed furnaces. The backfire explosion can be prevented effectively by non-premixed combustion, but the literature has shown poor gas mixing and inefficient combustion, especially in shallow beds. The LPG combustion in a fluidized bed furnace with the jetting-mixing nozzle distributor was investigated [12]. The fluidized bed combustion of gases (FBCG) in a bed of an inert material differs from flaming combustion in a number of respects: efficient combustion is possible for gaseous fuels over a wide range of calorific values, the process temperature can be much lower than in flames, and it can be varied independently of the gas composition. Good gas-solids mixing and low pollutant emission could make the process attractive for recovering energy from waste gas streams carrying combustible contaminants. In order to use FBCG, the process must be understood and controlled [13].

\section{EXPERIMENTAL SET UP}

Test rig: The apparatus used is a vertical combustor which is first fed with mixture (LPG and Air) from the bottom through a distributor plate, which is consists of numerous nozzles (50 nozzles each has 7 holes with $2 \mathrm{~mm}$ diameter). The combustor is filled by sand or limestone particulates for limited height. The initial height of the bed determined from cold tests. These particulates are the fluidization medium. The particulates diameters are in range of (700:1000 $\mu \mathrm{m})$. Fig.1 shows the schematic diagram of the apparatus.

Air supply system: The combustion air is admitted from a centrifugal air blower to the combustor through a 4" steel pipe. The air mass flow rate was 
controlled by gate valve. The combustion air flow rate is measured by means of a calibrated orifice meter, which is connected to a U-tube water manometer.

Fuel supply system: The gaseous fuel flows from a pressurized gas cylinder, with LPG at about 3 bar. The average heating value and density are 45883.86 $\mathrm{KJ} / \mathrm{Kg}, 2.4 \mathrm{Kg} / \mathrm{m}^{3}$ respectively. The fuel flow rate is measured by means of a calibrated orifice meter before entering the mixing chamber.

Distributor plate: The aim of the distributor plate is to ensure that the mixture distributed across the area of the bed uniformly. The distributor diameter is 190 $\mathrm{mm}$. The distributor plate consists of 50 nozzles; each nozzle has 7 holes each with $2 \mathrm{~mm}$ diameter. Six holes are distributed radially and one axially. The nozzles are distributed in a radial manner with equal distance along the cross section area of the distributor. Fig. 2 shows the distributor plate and nozzles.

Flame trap: The idea of flame trap is to prevent the combustion wave to reach the mixing chamber where the gaseous fuel and oxidant are mixed and being explosive. The flame trap composed of multi copper tube, which quenches the flame wave by increasing the cooling area, which is presented, by circumertial area of the tube, and it is shown in Fig.3shows the flame trap.

The combustor: The combustor is a vertical cylindrical steel tube of $213 \mathrm{~mm}$ diameter and 1200 $\mathrm{mm}$ height. The combustor is surrounded by a cylindrical water jacket for cooling. The combustor contains on one vertical side, 10 tapping holes of 19 $\mathrm{mm}$ diameter arranged axially along the combustor to measure any desired phenomena, and it has in one side a glass window to see the fluidization in cold and hot states. There are two feeding cones on the top, one for solid fuels (wood ships and coal). The other cone for make-up the fluidized-bed particulates. Fig. 4 shows the combustor details. In the present work a fine wire thermocouple of Platinum - $6 \%$ Rahdium Vr. Platinum - $30 \%$ Rahdium of $0.3 \mathrm{~mm}$ in diameter is used for gas temperature measurements at some sections inside furnace volume. The probe has $14 \mathrm{~mm}$ in outer diameter and $0.5 \mathrm{~m}$ length. The heat transfer to the combustor wall was calculated from the increase of enthalpy of the cooling water. The water inlet and out let temperatures were measured by standard $\mathrm{K}$ type thermocouple. From the measured values of hot gases leaving the combustor and the heat transferred to the combustor walls, the combustion efficiency at each run was calculated.

\section{EXPERIMENTAL RESULTS AND DISCUSSION}

\subsection{Cold Tests}

For a typical experiment the cold bed material, after selection for type, mass and particle size placed into the combustor. Two cold tests were made by sand and limestone particulates to determine the best initial height of the bed particulates, which makes a good fluidization. Fig. 5 shows the fluidization of the bed and the corresponding height with increasing the mixture (air and fuel) flow rate for sand particulates while Fig. 6 show the fluidization of the bed and the corresponding height. The best initial height observed to be $[5 \mathrm{~cm}]$. The bed height of fluidizedbed by limestone particulates is greater than the bed height of fluidized-bed by sand particulates, it observed to be $[7 \mathrm{~cm}]$. Figure (7) shows the bed height against the mixture of air and LPG.

\subsection{Hot Tests}

In hot tests, the LPG fuel was burned with sand and limestone as bed materials. Heat balance was made to indicate the combustion efficiency from the following relation:

$$
\eta_{c}=\frac{m_{w} c_{p_{w}} \Delta T_{w}+m_{g} c_{p g} \Delta T_{g}}{m_{f} C . V}
$$

Where $\mathrm{m}_{\mathrm{w}}=$ cooling water mass flow rate $\mathrm{kg} / \mathrm{sec}$., $\mathrm{C}_{\mathrm{pw}}=$ specific heat of water $\mathrm{kJ} / \mathrm{kg} \cdot \mathrm{K}, \Delta \mathrm{T}_{\mathrm{w}}=$ cooling water temperature difference, $\mathrm{m}_{\mathrm{g}}=$ flowing gases mass flow rate $\mathrm{kg} / \mathrm{sec}, \mathrm{C}_{\mathrm{pg}}=$ specific heat of gases $\mathrm{kJ} / \mathrm{kg} . \mathrm{K}, \mathrm{m}_{\mathrm{f}=}$ fuel mass flow rate $\mathrm{kg} / \mathrm{sec}$ and $\mathrm{C} . \mathrm{V} .=$ heating value of the fuel $\mathrm{kJ} / \mathrm{kg}$.

\subsubsection{Sand hot tests}

Four experiments were conducted to show the effect of changing the momentum fluxes of air-fuel mixture mass flow rate (with constant air to fuel ratio) on the fluidization characteristics, gas temperature distribution along the combustor height and the combustion efficiency. Figures (8) to (11) represent the fluidization characteristics and the gas temperature distributions, while the calculated combustion efficiency is presented as values with every experiment. Figure (16 - a) represents the combustion efficiency for the four experiments, while figure (17 - a) represents the recorded maximum gas temperature through the tests. From the observation from these figures, it can see the following:

- The gas temperature distributions show the same trend as the maximum gas temperature values are observed just above the fluidized height and progressively decreased as the distance from the bed increased.

- The maximum gas temperature values are slightly increased with increasing the mixture mass flow 
rate about $50 \mathrm{~g} / \mathrm{s}$ and decreased with more increase in the mixture flow rate.

- Increasing the mixture mass flow rate giving more effective fluidization and the gas temperature values at the combustible exit are progressively increased due to the increase of the input heat values of the mixtures.

- As the combustible mixture increased, the combustion efficiency is increased as the result of intense combustion resultant from the higher fluidization.

\subsubsection{Limestone hot tests}

Another four experiments were conducted using limestone as bed material instead of sand with the same operating conditions. Figures (12) to (15) represent the fluidization characteristics and the gas temperature distributions. Figure $(16-b)$ represents the combustion efficiency for the four experiments, while figure $(17$ - b) represents the recorded maximum gas temperature through the tests. From the observation from these figures and photos, it could be seen that:

$>$ Using limestone enhance the fluidization process

$>$ The gas temperature distributions along the combustor height are similar as compared the sand bed material.

$>$ The measured gas temperature value for the limestone bed material is slightly higher as compared with the sand bed material.

$>$ The combustion efficiency are enhanced and reached its higher values faster than those of the sand bed material reach.

Finally, two experiments were conducted using a crashed coal particle (diameter ranging from 0.2 $0.5 \mathrm{~mm}$ ) and wood ships (diameter ranging from 0.3 $-0.6 \mathrm{~mm}$ ) with using a lesser quantities of LPG fuel $(0.3121 \mathrm{~g} / \mathrm{s})$.the solid fuels are continuously fed by using a particle feeder to the combustor. Photos (18) and (19) show the combustion of those two kinds of the solid fuel with the sand bed material. It could prove that the ability design of the experiment test rig to fire any kind of the solid fuels by using the fluidization techniques.

\section{CONCLUSION}

A number of experiments have been carried out for a cylindrical fluidized bed combustor using sand and limestone as bed materials and LPG as fuel; carry information on the combustion process. Based on the information and data presented, the following findings were obtained:

\section{For cold tests}

- Increasing the momentum flux the bed height increased.

- The bed height in limestone is greater than the bed height in sand.

\section{For hot tests}

- The bed height in hot tests is greater than cold tests for similar conditions.

- When we increase the momentum flux the average temperature increase.

- The temperature difference between the lower section and the higher section decrease.

- Using limestone enhance the fluidization process.

- High combustion efficiency obtained.

- The combustion efficiency are enhanced and reached its higher values faster than those of the sand bed material reach.

- The ability design of the experimental test rig to fire any kind of the solid fuels by using the fluidization techniques.

\section{REFERENCES}

[1] N. O. Simeon, "Fluidized bed combustion", Marcel Dekker, Inc. (2004).

[2] Bartels M., Lin W., Nijenhuis J., Kapteijn F. and van Ommen R. J., "Agglomeration in fluidized beds at high temperatures: Mechanisms, detection and prevention", Energy and Combustion Science Vol.34 pp.633- 666 (2008).

[3] McKendry P.," Energy production from biomass (Part 2): conversion Technologies", Bioresource Technol, Vol. 83(1) pp. 47-54 (2002).

[4] Geldart D., “Types of gas fluidization", Powder Technology, Vol. 7 pp. 285-292(1973).

[5] Glicksman L.R., Hyre M., Woloshun K.,"Simplified scaling relationships for fluidized beds", Powder Technology, Vol.77, pp.177199(1993).

[6] Rholdes M.,'Introduction to particle technology", 2nd Edition, John Wiley \& Sons Ltd, (2008).

[7] Geldart D., "The design of distributors for gasfluidized beds", Powder Technology, Vol. 42 pp. 67-78(1985).

[8] Chyang C., Lieu K. and Hong S., "The effect of distributor design on gas dispersion in a bubbling fluidized bed", Journal of the Chinese Institute of Chemical Engineers, article in press , (2008).

[9] Gayan, P., L. F. Dediego, and J. Adanez, "Radial Gas Mixing in a Fast Fluidized-Bed", Powder Technology, Vol. 94, pp. 163- (1997).

[10] Namkung, W. and S. D. Kim, "Radial Gas Mixing in a Circulating Fluidized Bed," Powder Technology, Vol. 113, pp. 23- (2000).

[11] Baron, J. Bulewicz E.M., ZukowskW. Kandefer S. and Pilawska M.,"Combustion of hydrocarbon fuels in a bubbling fluidized bed", Combustion and Flame Vol.128 pp 410421(2002). 
[12] Wang L., Wu P. and Ni X., "Combustion of liquid petroleum gas in a fluidized bed furnace with a jetting-mixing distributor" Powder Technology, Vol.170, pp. 86-93,(2006).
[13] Zukowski W.," Acoustic effects during the combustion of gaseous fuels in a bubbling fluidized bed", Combustion and Flame, Vol.117, pp. 629-635, (1999).

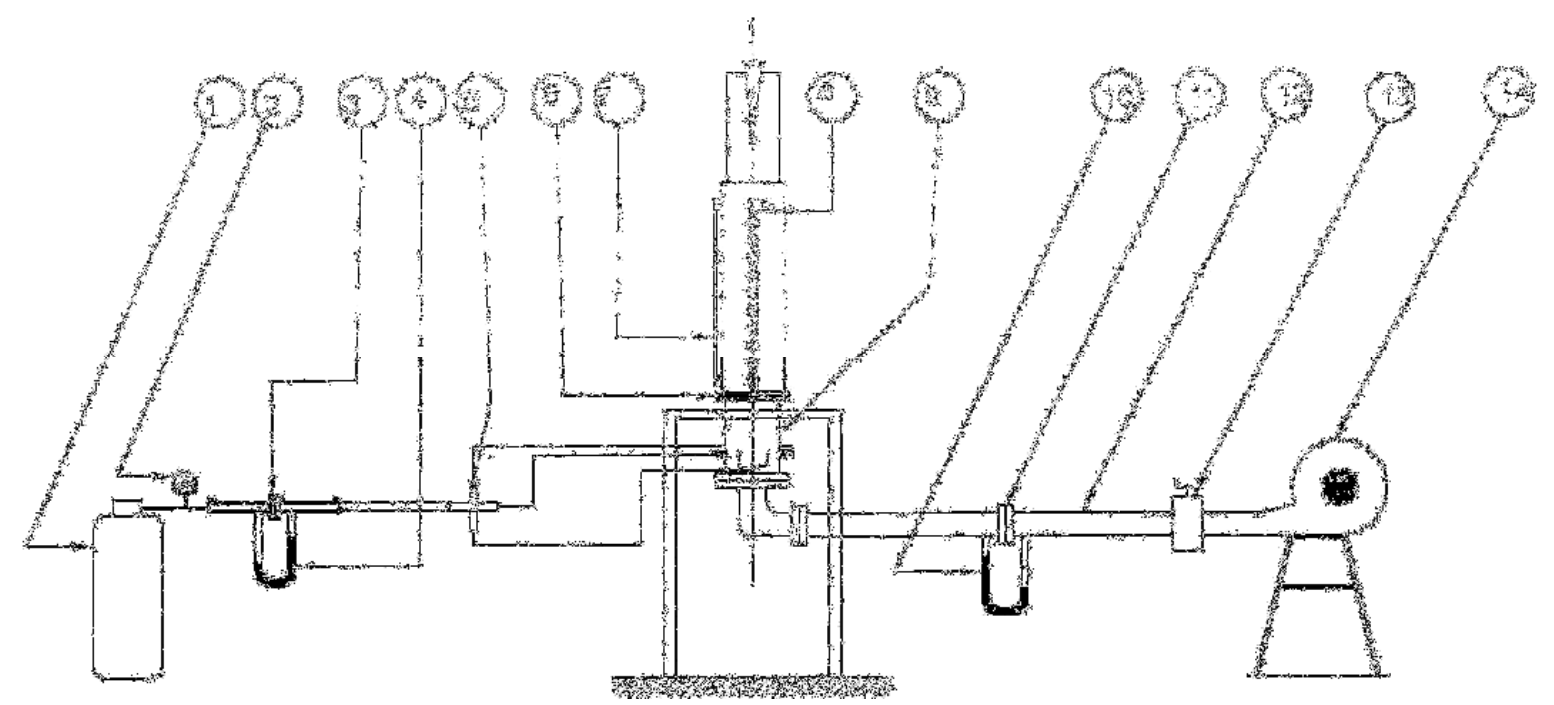

Fig. 1 Experimental test rig

\section{1-Gas bottle}

2- Pressure regulator

3- Orifice meter

4- U-tube manometer

5- Gas distributor
6- Distributor plate

7- Glass window

8- Cooling water out

9- Flame trap

10- U -tube manometer
11- Orifice meter

12- Air duct

13- Control valve

14- Air blower
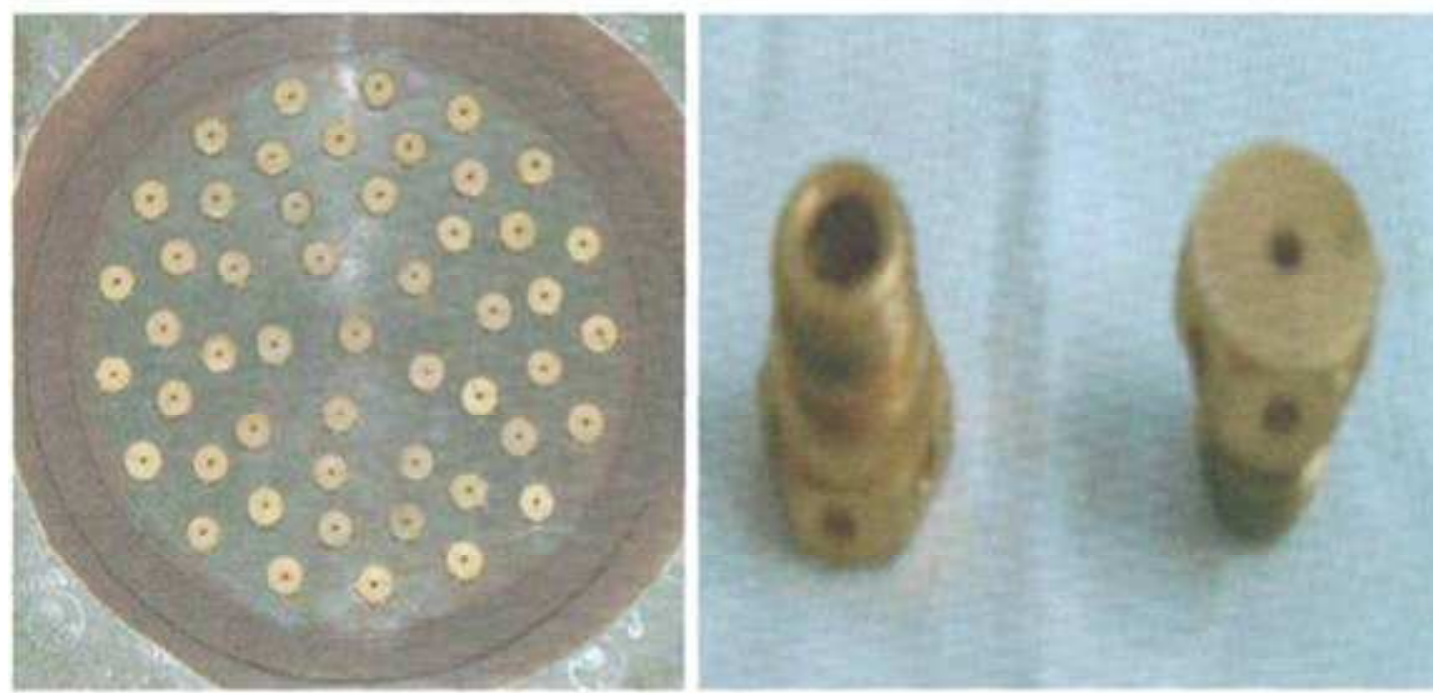

Fig. 2 Distributor plate and nozzles 


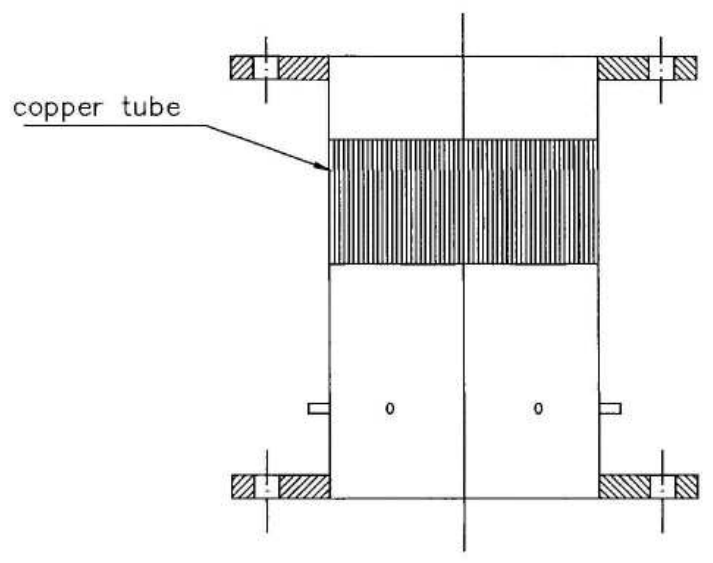

Sectional at A-A

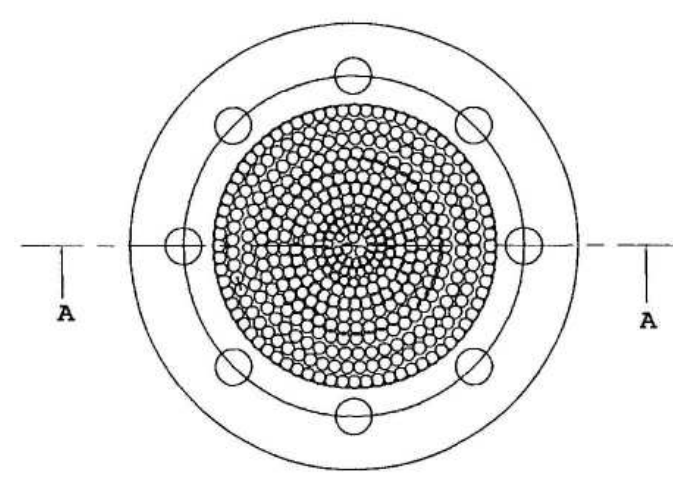

Plane

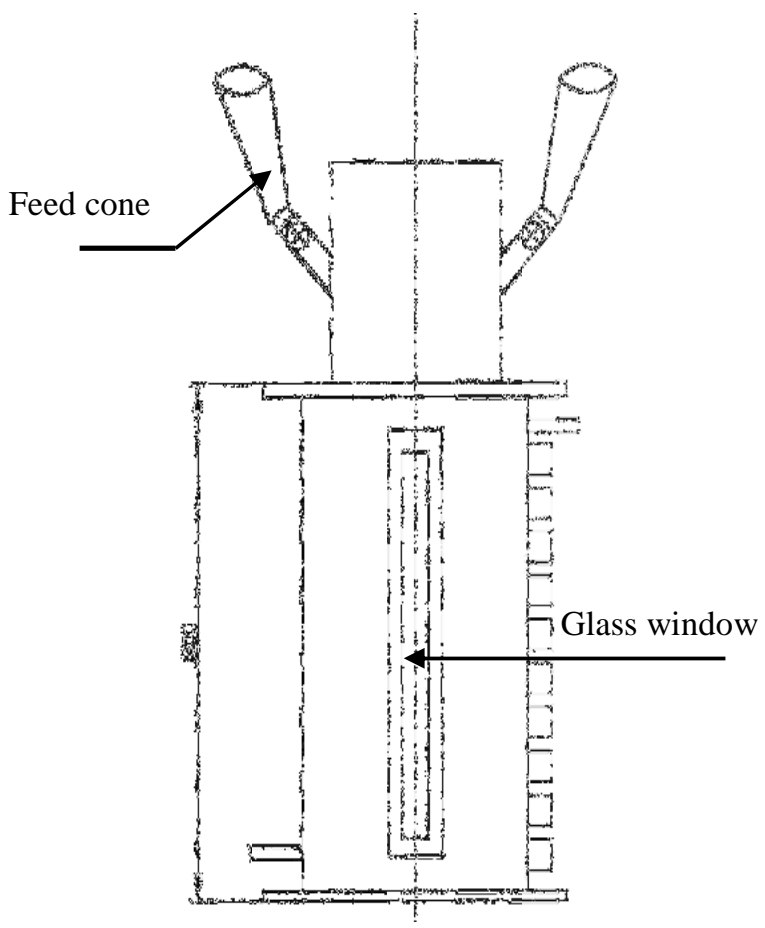

Fig.3 The flame trap

Fig. 4 The combustor details

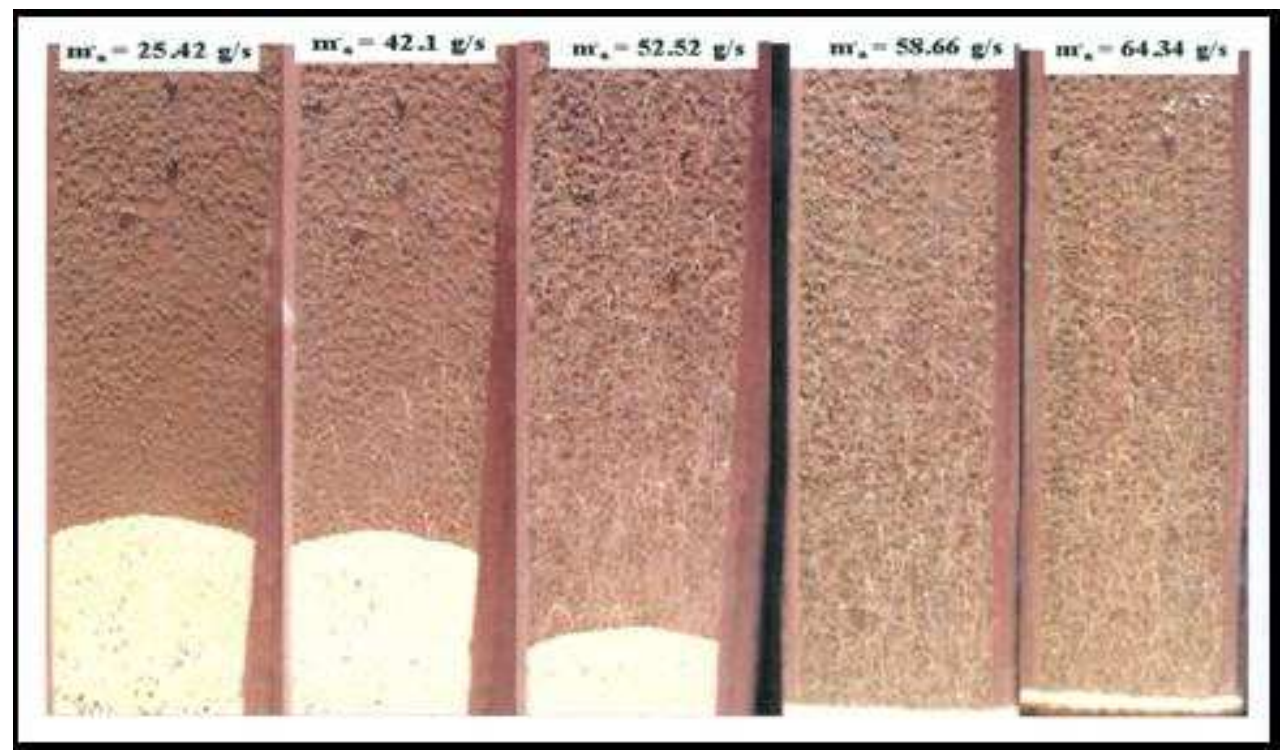

Fig. 5 Sand cold tests 
Shabaan, M. M, "Effect of Bed Material Type on Combustion Efficiency of Fluidized Bed Combustor"

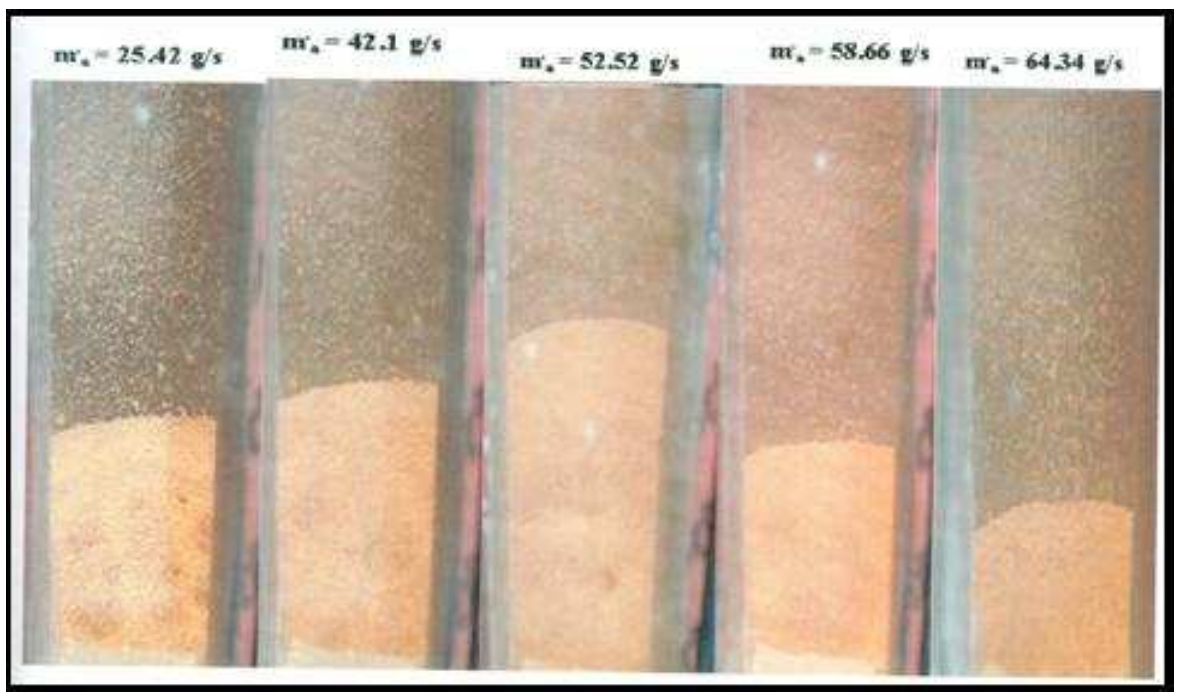

Fig. 6 Limestone cold tests
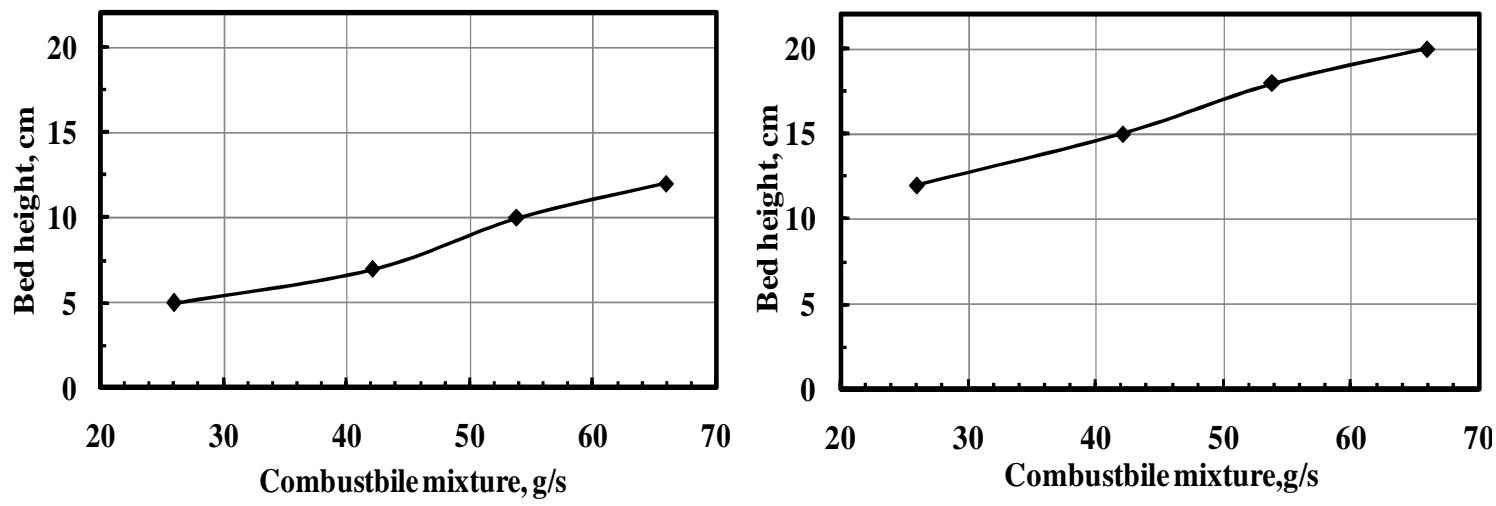

Fig. 7 Bed height for sand and limestone
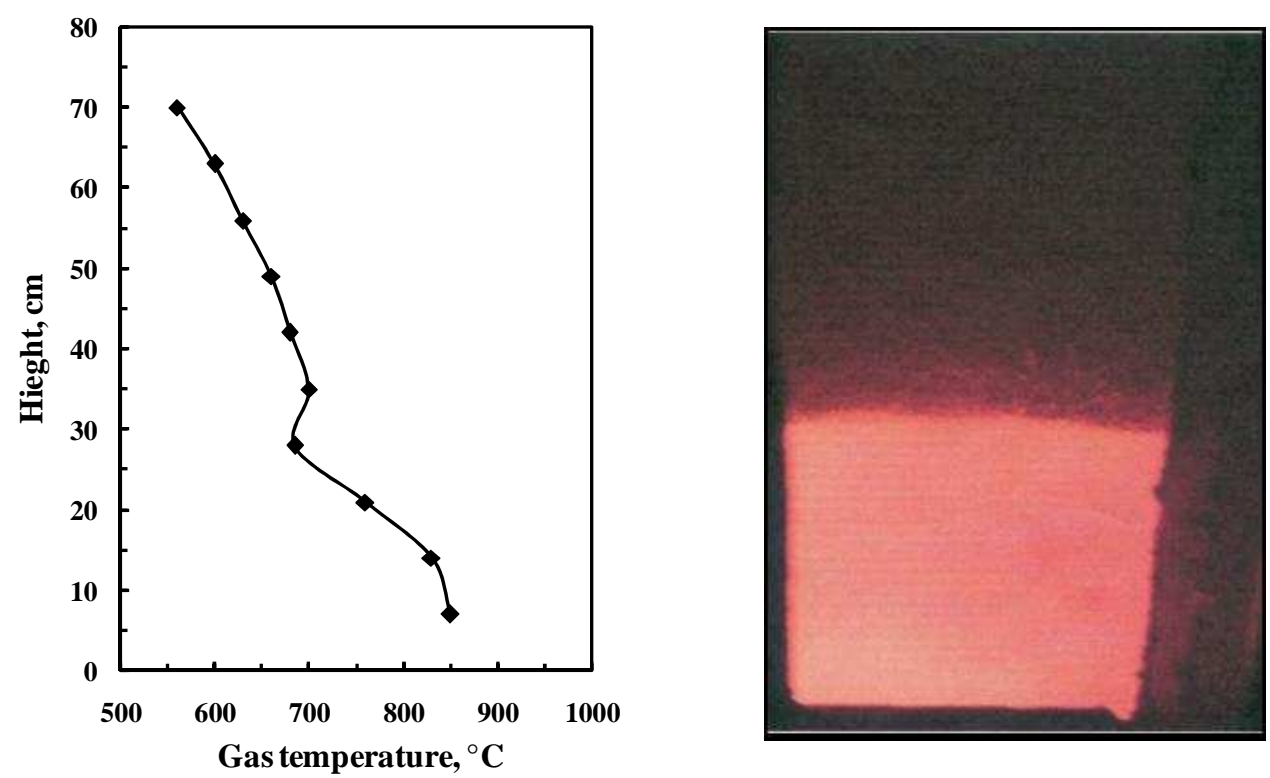

Fig. 8 Gas temperature distribution along combustor height and a photo for fluidized bed Fuel: $\mathrm{LPG}, \mathrm{m}_{\mathrm{f}}=0.6335 \mathrm{~g} / \mathrm{s}, \mathrm{m}_{\mathrm{a}}=25.4 \mathrm{~g} / \mathrm{s}$. Bed material: Sand 
Shabaan, M. M, "Effect of Bed Material Type on Combustion Efficiency of Fluidized Bed Combustor"
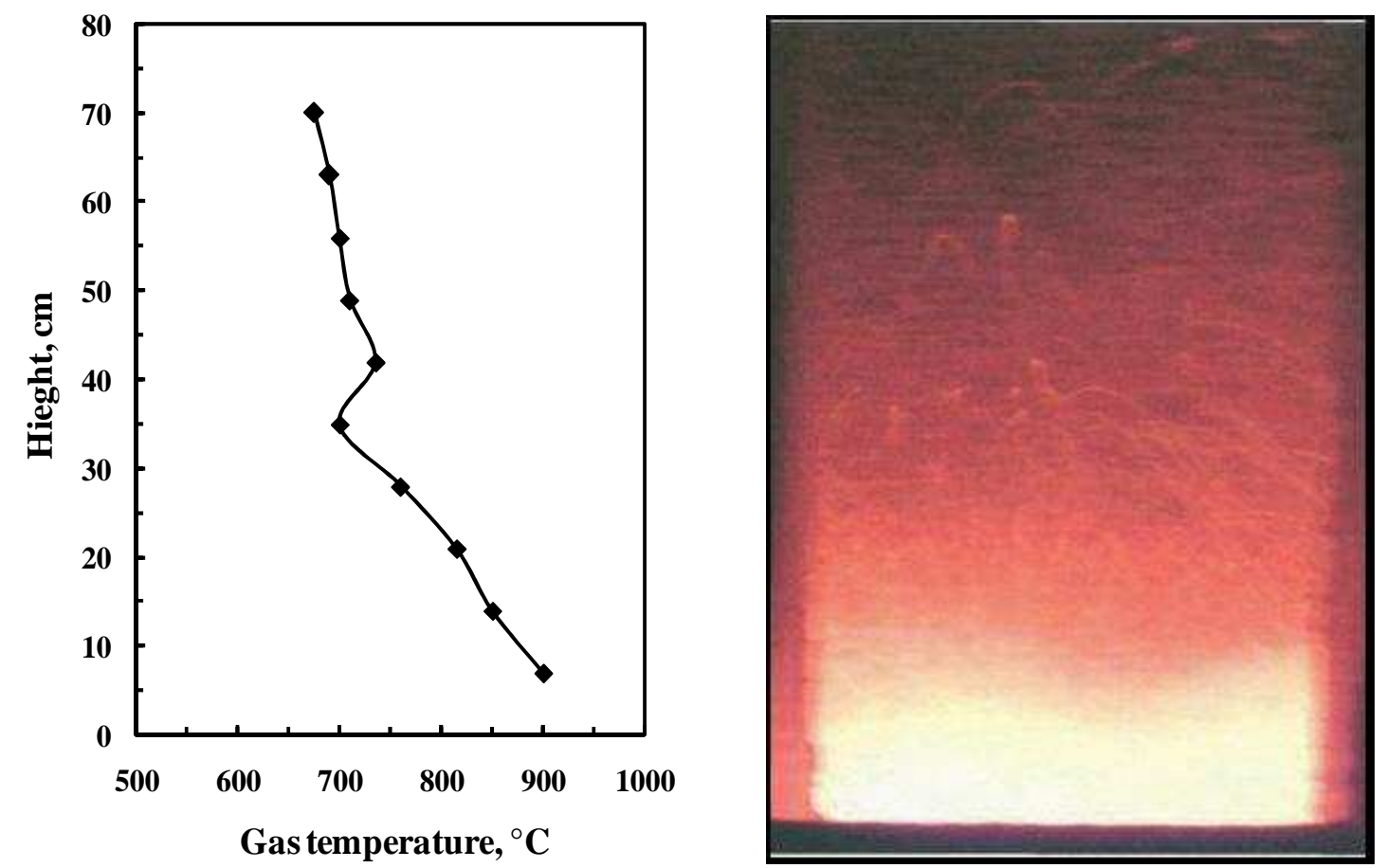

Fig. 9 Gas temperature distribution along combustor height and a photo for fluidized bed Fuel: $\mathrm{LPG}, \mathrm{m}_{\mathrm{f}}=1.027 \mathrm{~g} / \mathrm{s}, \mathrm{m}_{\mathrm{a}}=41.1 \mathrm{~g} / \mathrm{s}$. Bed material: Sand
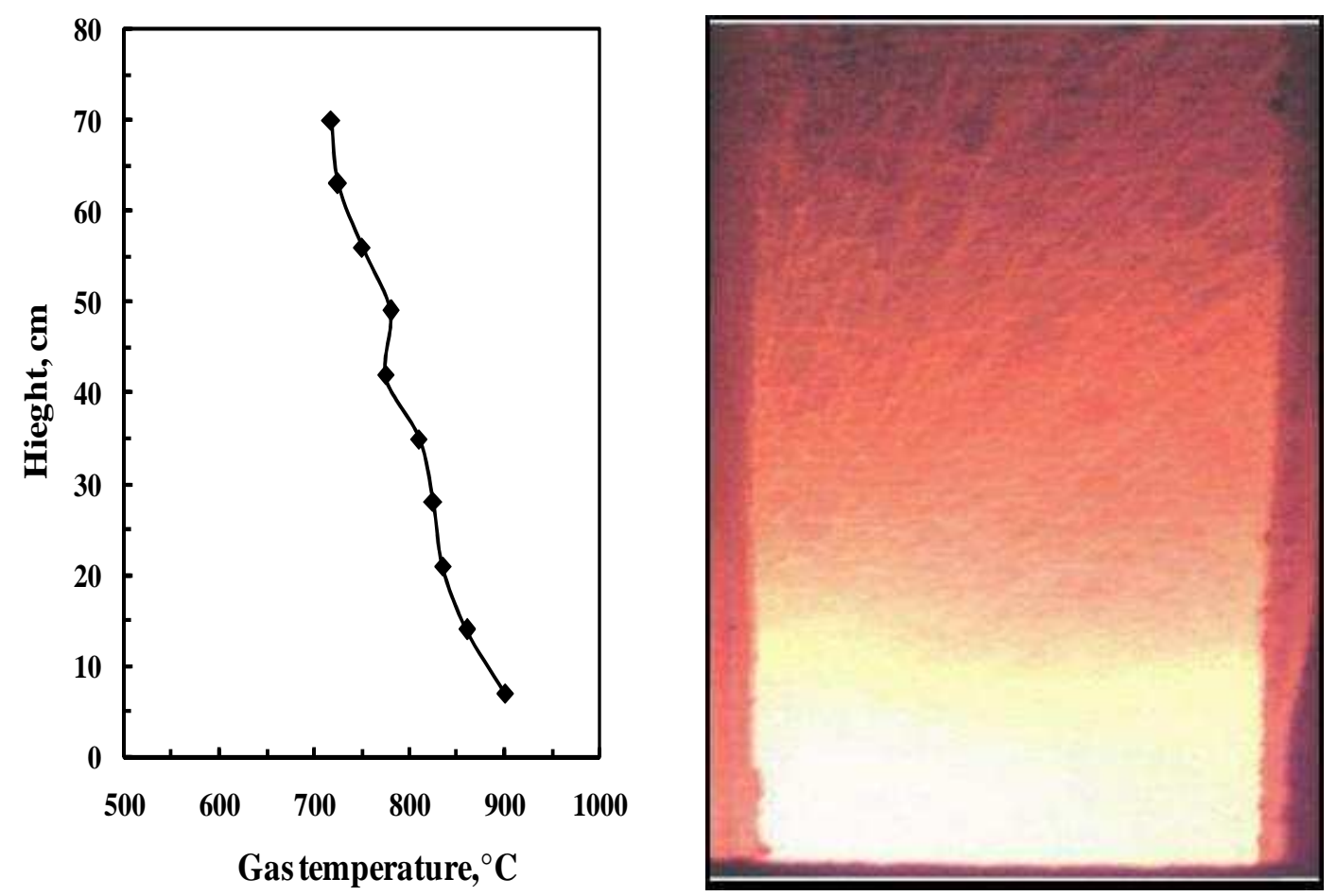

Fig. 10 Gas temperature distribution along combustor height and a photo for fluidized bed Fuel: $\mathrm{LPG}, \mathrm{m}_{\mathrm{f}}=1.313 \mathrm{~g} / \mathrm{s}, \mathrm{m}_{\mathrm{a}}=52.52 \mathrm{~g} / \mathrm{s}$. bed material: sand 
Shabaan, M. M, "Effect of Bed Material Type on Combustion Efficiency of Fluidized Bed Combustor"
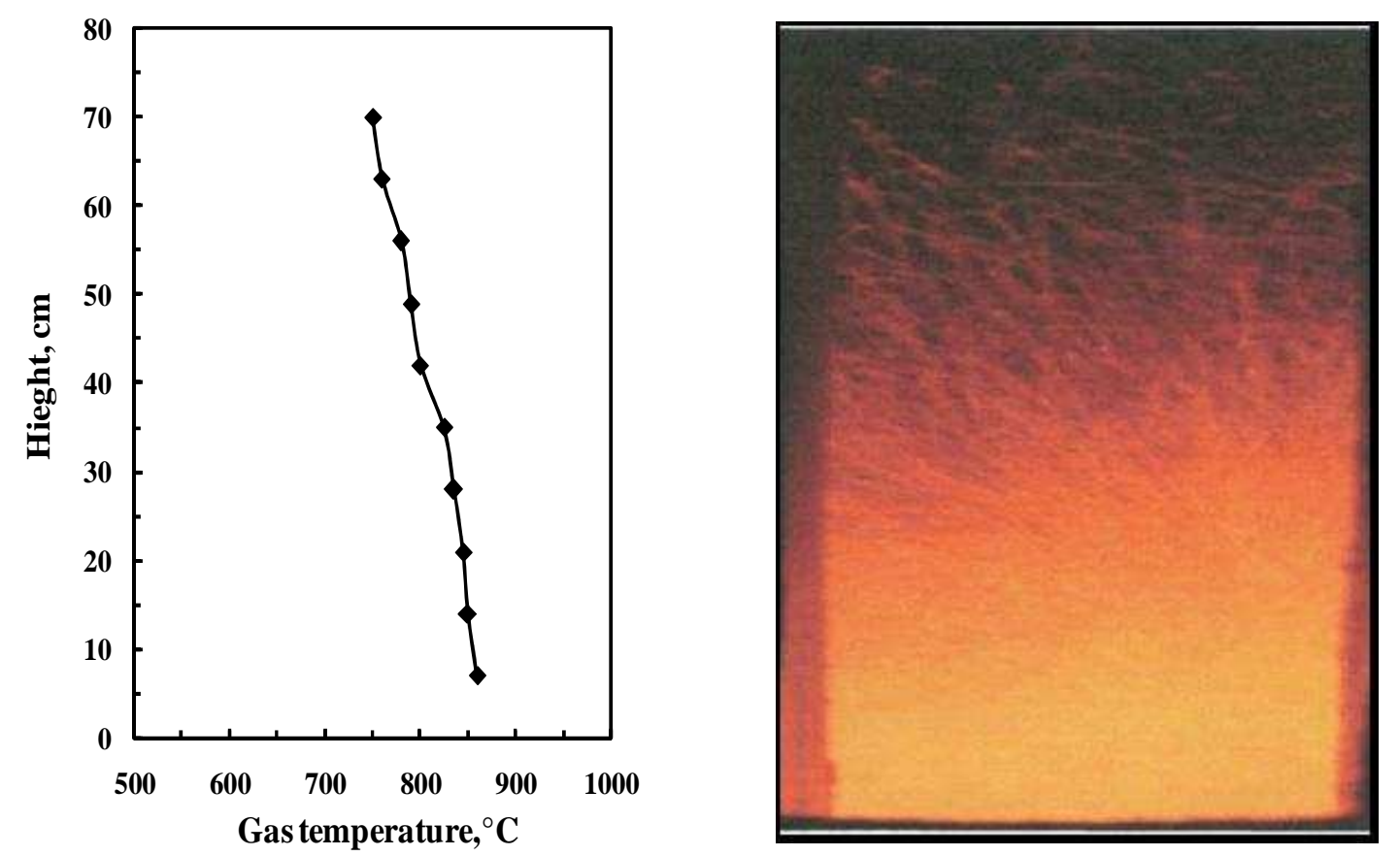

Fig. 11 Gas temperature distribution along combustor height and a photo for fluidized bed Fuel: $\mathrm{LPG}, \mathrm{m}_{\mathrm{f}}=1.608 \mathrm{~g} / \mathrm{s}, \mathrm{m}_{\mathrm{a}}=64.34 \mathrm{~g} / \mathrm{s}$. Bed material: Sand
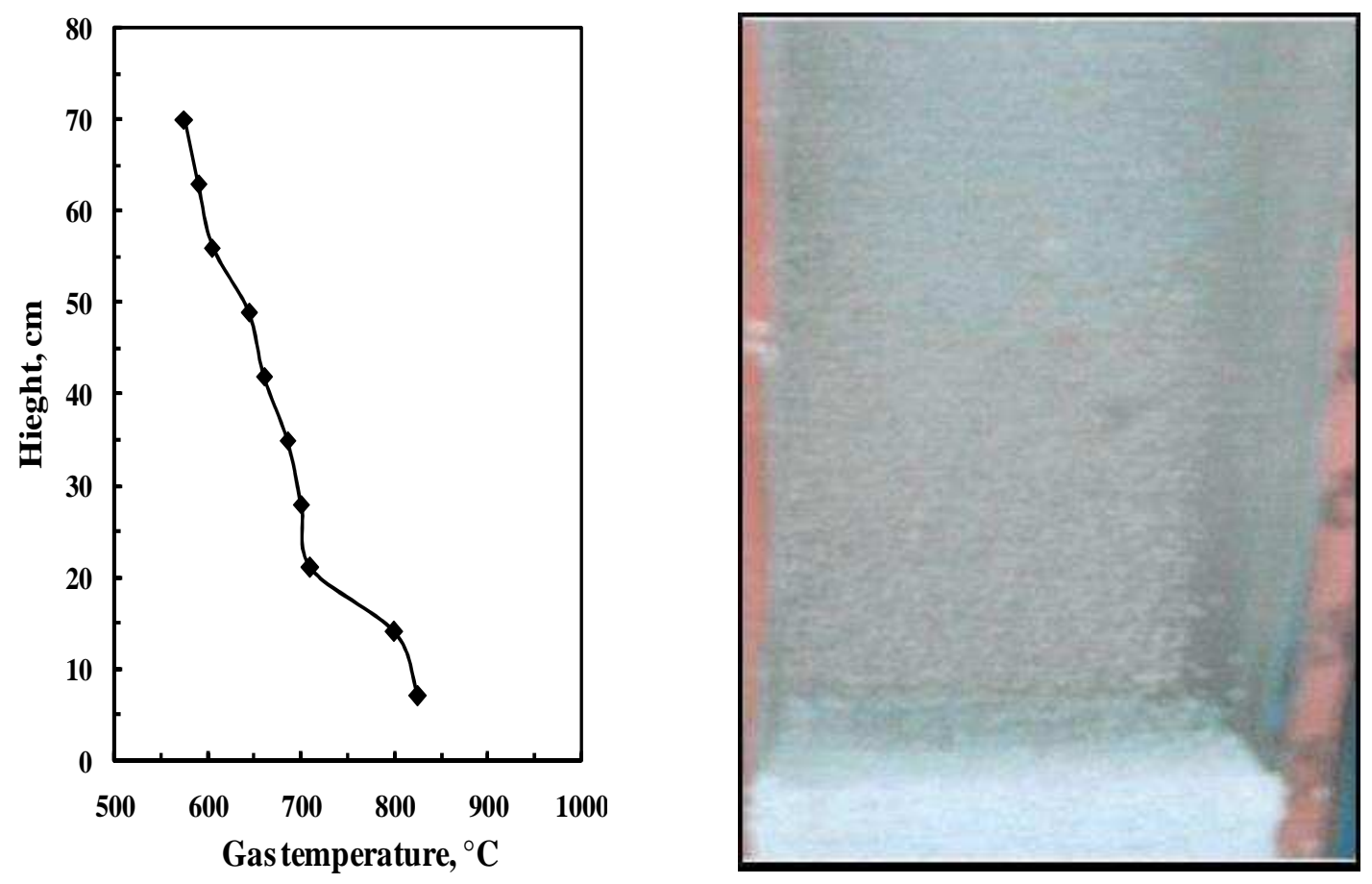

Fig. 12 Gas temperature distribution along combustor height and a photo for fluidized bed Fuel: $\mathrm{LPG}, \mathrm{m}_{\mathrm{f}}=0.6335 \mathrm{~g} / \mathrm{s}, \mathrm{m}_{\mathrm{a}}=25.42 \mathrm{~g} / \mathrm{s}$. Bed material: Limestone 

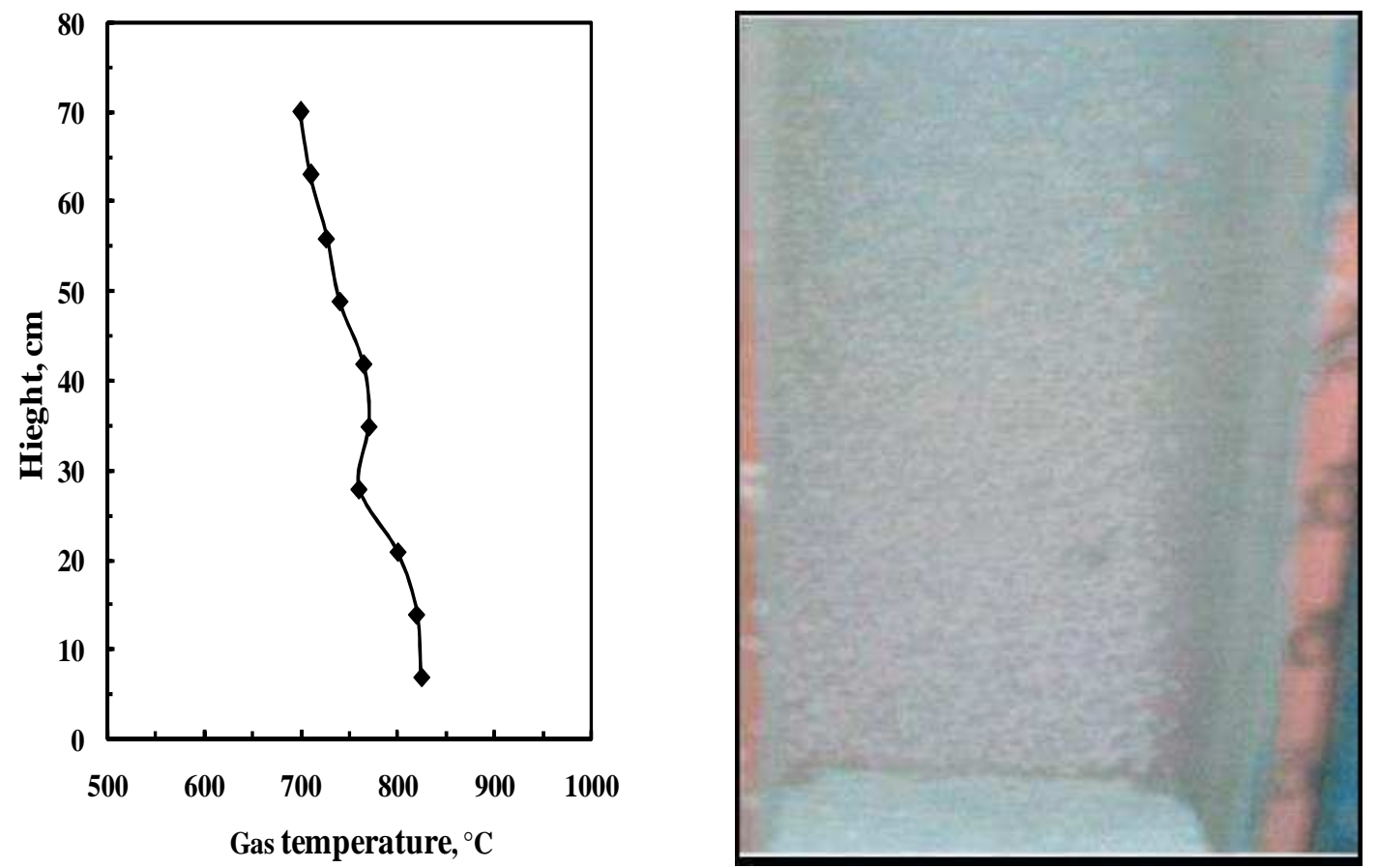

Fig. 13 Gas temperature distribution along combustor height and a photo for fluidized bed Fuel: $\mathrm{LPG}, \mathrm{m}_{\mathrm{f}}=1.0275 \mathrm{~g} / \mathrm{s}, \mathrm{m}_{\mathrm{a}}=41.1 \mathrm{~g} / \mathrm{s}$. Bed material: Limestone
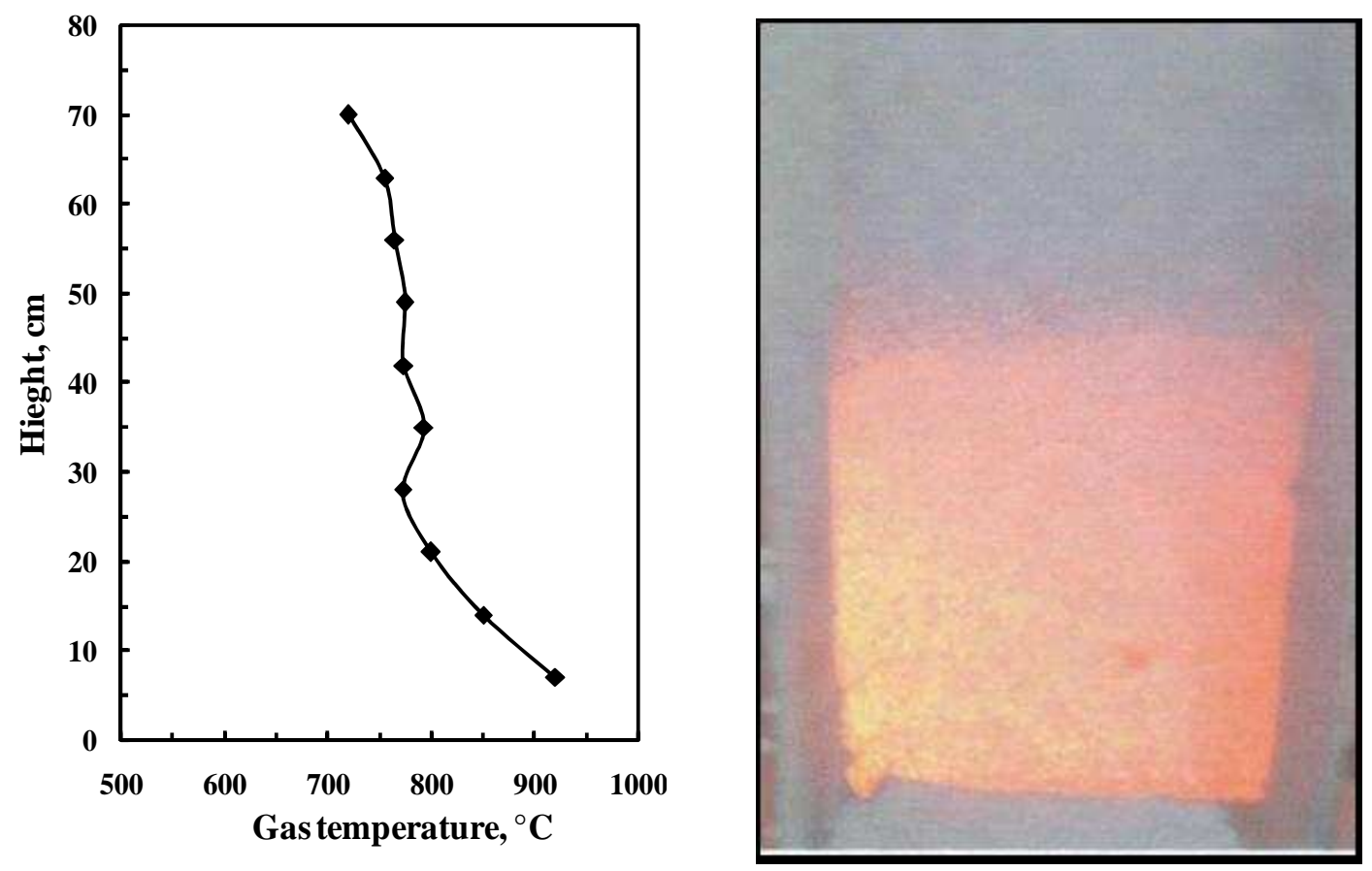

Fig. 14 Gas temperature distribution along combustor height and a photo for fluidized bed Fuel: $\mathrm{LPG}, \mathrm{m}_{\mathrm{f}}=1.313 \mathrm{~g} / \mathrm{s}, \mathrm{m}_{\mathrm{a}}=52.52 \mathrm{~g} / \mathrm{s}$. Bed material: Limestone 

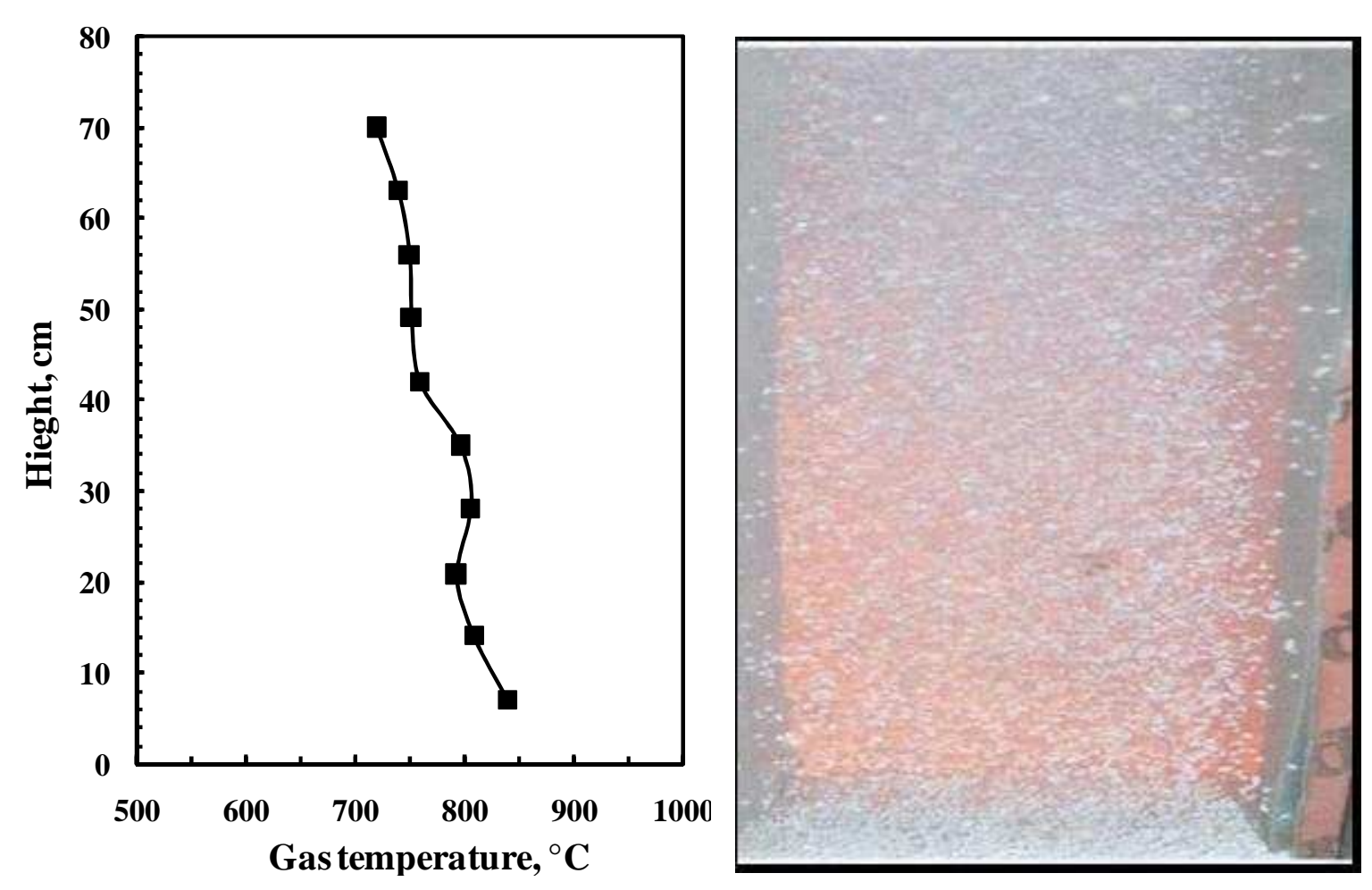

Fig. 15 Gas temperature distribution a long combustor height and a photo for fluidized bed Fuel: $\mathrm{LPG}, \mathrm{m}_{\mathrm{f}}=1.4665 \mathrm{~g} / \mathrm{s}, \mathrm{m}_{\mathrm{a}}=58.66 \mathrm{~g} / \mathrm{s}$. Bed material: Limestone

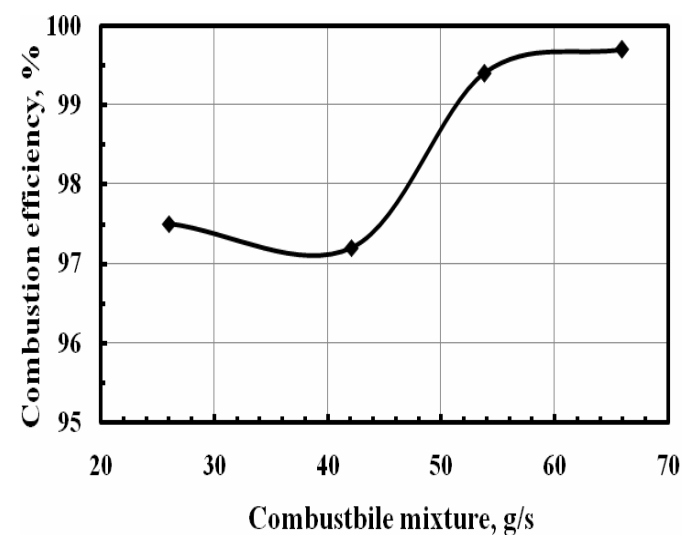

(a) Sand

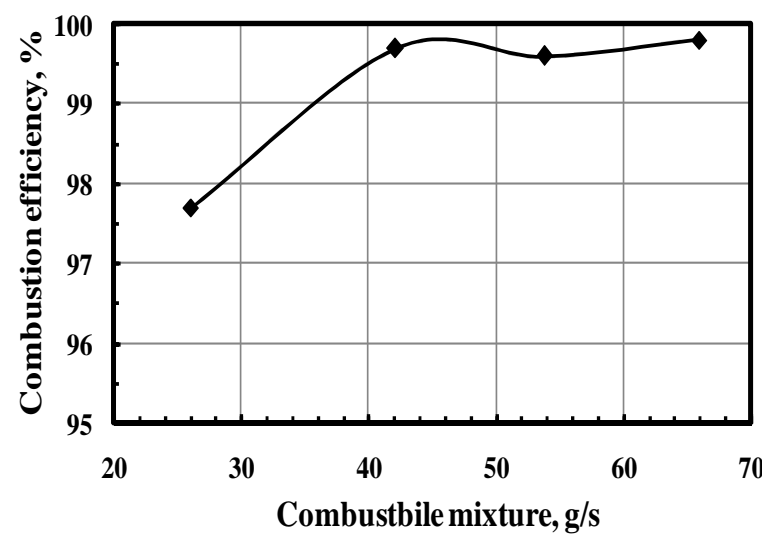

(b) Limestone

Fig. 16 Combustion efficiency 
Shabaan, M. M, "Effect of Bed Material Type on Combustion Efficiency of Fluidized Bed Combustor"

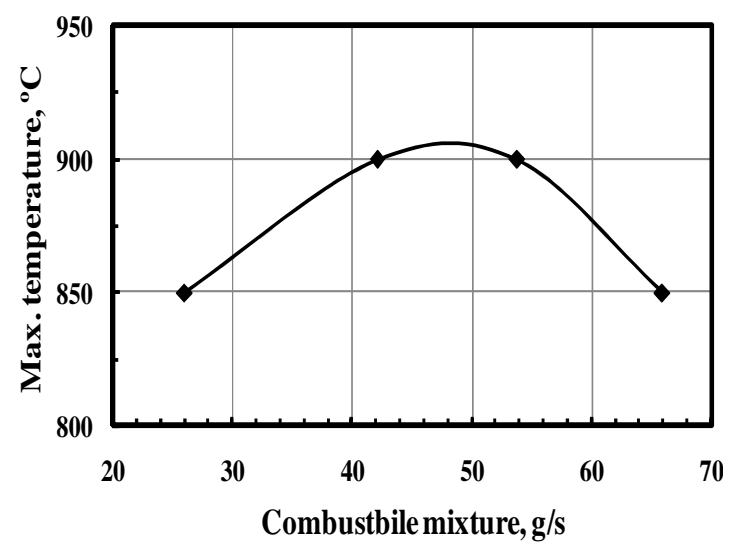

(a) Sand

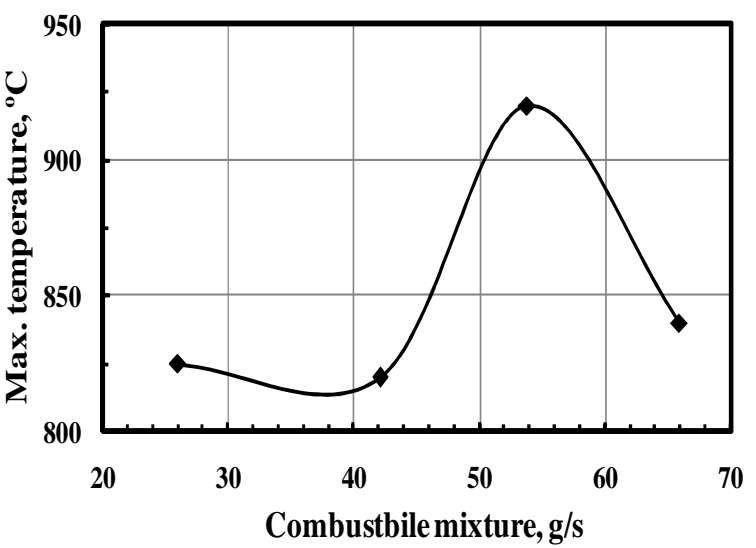

(b) Limestone

Fig. 17 Maximum temperature

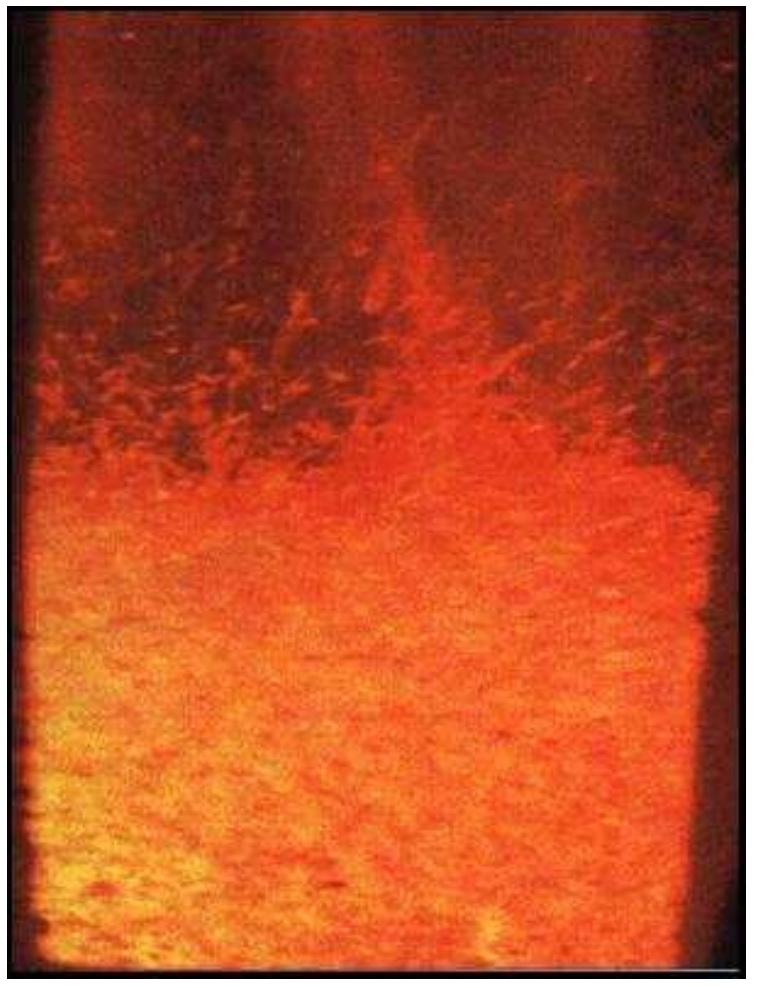

Fig. 18 A photo for fluidized bed using coal $\mathrm{m}_{\mathrm{LPG}}=0.3121 \mathrm{~g} / \mathrm{s}, \mathrm{m}_{\mathrm{Coal}}=1.092 \mathrm{~g} / \mathrm{s}, \mathrm{m}_{\mathrm{a}}=41.1 \mathrm{~g} / \mathrm{s}$. Bed material: sand

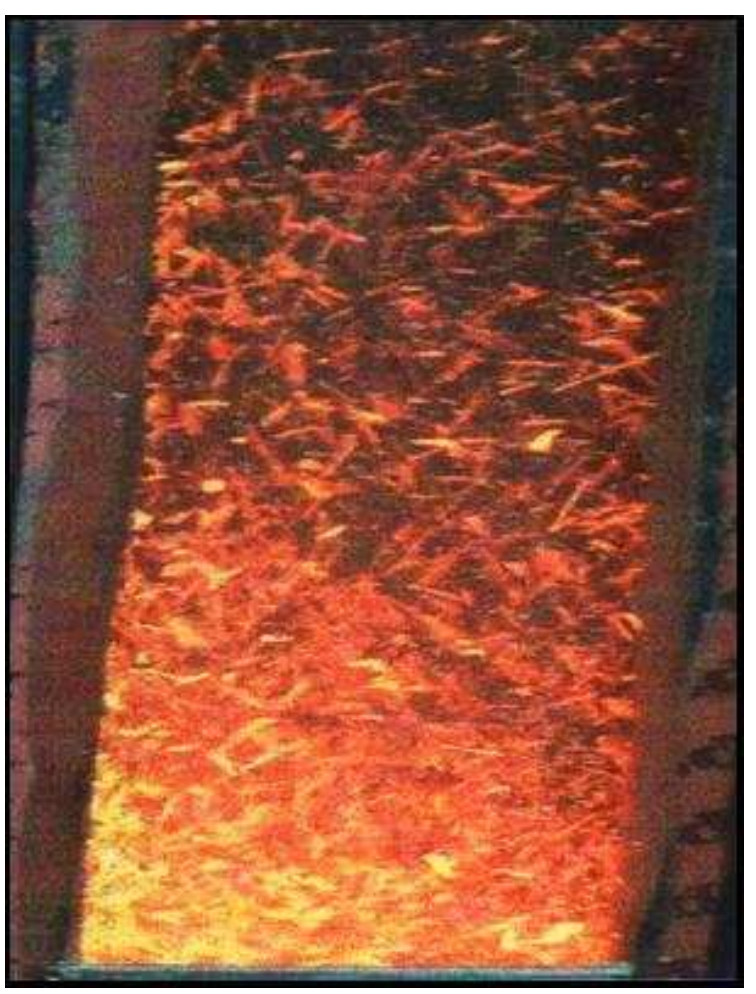

Fig. 19 A photo for fluidized bed using wood ships $\mathrm{m}_{\mathrm{LPG}}=0.3121 \mathrm{~g} / \mathrm{s}, \mathrm{m}_{\text {wood ships }}=1.092 \mathrm{~g} / \mathrm{s}, \mathrm{m}_{\mathrm{a}}=41.1 \mathrm{~g} / \mathrm{s}$ Bed material: sand 